\title{
BUSINESS ETHICS AND INFORMATION
}

\author{
Slavica PRVULOVIĆ ${ }^{1}$, Marija MATIĆ ${ }^{2}$, Dragiša TOLMAČ $\check{C}^{2}$ \\ ${ }^{1}$ University of Novi Sad, Technical faculty "Mihajlo Pupin” in Zrenjanin, 23000 Zrenjanin, Đure Đakovica bb, \\ Republic of Serbia. E-mail: prvulovicslavica@ yahoo.com \\ ${ }^{2}$ University of Novi Sad, Technical faculty "Mihajlo Pupin" in Zrenjanin, 23000 Zrenjanin, Đure Đakovica bb, \\ Republic of Serbia
}

Accepted 17 November, 2012

\begin{abstract}
Application of business ethics in journalism was considered in the paper. The analysis of the extent of application and following ethic codes, company privacy and personal privacy was completed. The results of a survey are presented. The survey was conducted and it refers to: the amount of time twhich respondents spend watching TV, whether they regularly read daily newspapers, what is their opinion about journalists, how much they trust the journalists, whether the journalists are corrupted and to what extent, whether the journalists are politicized and to what extent, etc. Based on theoretical considerations and the gained results of the research the conclusions about the ethical conduct of the journalists and media in Serbia were established.
\end{abstract}

Keywords: business ethics, ethical codes, journalism, media.

\section{INTRODUCTION}

In the modern world, we often witness the destruction of basic ethical principles. Our ethical behavior depends on the situation, because the moral boundary, which will guide through decision-making is vanishing. Core values and ethical principles are often neglected as well as the norms, which have been respected since the beginning of the world. If in this kind of thinking we include the media, confusion becomes even greater (Guilmot, 2008). The media had moved long time ago from the field of information into the field of scandals, where the ethical codes mean nothing, they are irrelevant and disrespected (Calabrese, 2007).

Ethics in media and journalism really is a set of rules regulating what is, what is not allowed in the media, what is on the borderline, and what is a potential threat to some political and social values . Ethics in media is not a set of laws and legislative rules that the state directs and encourages though its actions. Ethics belongs to the assessment of profession, i.e. what in the profession is allowed, acceptable and what is not (Day, 2004). There is no doubt that there are some global standards that do not depend only on the nature of a society or conditions in a country. Nothing, not even a reference to ethical principles must not undermine the freedom of expression, nor anyone has a monopolistic position in society to determine what is and is not ethical, thereby to prevent saying something in public (McLuhan, 2001).

\section{MATERIAL AND METHOD}

\section{The concept of business ethics and basic ethical principles}

Business ethics is a branch of general ethics. Under the business ethics social responsibility is implied, which includes the good and bad behavior towards other people, in the form of a set of rights and duties that people apply during the decision making process. There is also an obligation to perform the job properly and the responsibility for its (non) performance. Morally responsible person is obliged to do the job and is ready to accept the responsibility for a failure or a possible error. Business ethics can be defined as a set of moral standards on the behavior towards the sociocultural and business environment, towards other individuals with whom one enters into a business relationship and towards duties, obligations, rights, responsibilities and decision-making in all aspects and areas of operation (Prvulovic, 2006). 
Business people, economists, analysts and researchers, have constant arguments whether a certain dose of "cheating" and "lies" in business is necessary. Is that kind of game inevitable, and whether it is present consciously or unconsciously in every market game and every business communication? The desire for profit, for business success, for gaining the advantage on the market, as well as for personal gain, wealth, represents a challenge for individuals and groups to leave sometimes the established rules of the game in order to gain advantage in competition with others.

All this may lead to the thesis that business success and ethics cannot go together. The main issue that arises in such situations is: Where is the boundary that determines whether something in business is moral or not? It is justified from a moral point of view as long as you stay within the unwritten rules of business and market game, this is called " business bluffing " (Carr, 1968).

Bearing in mind the importance of boundaries in business, business relations and business communication, business ethics may be determined as a set of personal and collective moral practices that are used in all types of business activities, and which determine the extent to which one can go, and that those activities, procedures and decisions do not result in a negative attitude within the company and its environment, and not to create unnecessary costs and damage to the company and the environment (Hitt and Collins, 2007). The boundaries can be within the legal norms and rules, then within good business relations and habits in the economic and social surrounding, and within the personal position and situation in relation to others with which one comes into business contact.

\section{Ethics in journalism}

The journalists have reason to be suspicious when it comes to ethics in the media and journalism, even when it is stated that under the ethics a set of norms is understood, the principles or rules of trade that are prescribed by the journalists themselves and their organizations (White, 1996). That term will, apparently, first associate to a kind of hypocrisy, or a call to self-censorship: to involve themselves in prescribing and limiting of the free action field, to define for themselves the criteria of their profession and professionalism in journalism, and then publicly warn their colleagues who violate the rules and exceed the specified limits.
In the modern democratic society everyone can, under equal and determined by the law conditions establish their own media; to start one's own newspaper, or to apply for a license for radio or television station. As one can - under the same conditions stipulated by the law - begin to do any other business: to establish a private school, to open a factory, a farm ... But, in order to do the intended one must be able to meet all necessary requirements and standards that such activity entails. In the case of the media, those relating to human rights to be properly informed, the right to protect one's privacy and the protection of all other basic human rights that might be related to the information.

In contrast to traditional media regulations, which rest on the belief that all problems in this area can be solved by disciplining non-professional journalists, real ethical codes of professional journalists, which will be shaped by the journalists themselves, begin, basically, from from the protection of significantly different values and interests. Primarily protecting their professional interests, journalists are, by nature, most interested in the recognition and protection of a basic human right of every man to be truthfully, timely and properly informed about everything that could be of one's concern (Himelboim and Limor, 2008).

The problem, however, is that many journalists are often not aware of that fact, that despite a long, rich and turbulent history of journalism in Serbia, local professional journalists often lack the specific knowledge and experience necessary to act in a truly democratic environment. They lack the awareness of the importance of a professional organization, the awareness of the true meaning and importance of basic values on which the journalistic profession should be established, the awareness of the true sense of ethical journalism, about the necessity of determining the true and valid ethical codes, the meaning and scope of the principle of regulations in this area (Guilmot, 2008). After all, in a society, which during its modern history - for good two hundred years - is in a kind of "transition", not one system of values was long lasting and well set.

Code of ethics for journalists and other media professionals is just another name for the "rules of the game" that are determined by the journalistic profession itself and which they are ready to respect (Marjanović, 2008). And, those rules make sense only if they are derived from a broader social context that is characterized by the acceptance of a 
certain system of universal values. The full and true meaning of ethical journalism can come into play only if it serves the fulfillment of fundamental human right and freedom of every person to have all the information of interest for the realization of all other freedoms and rights, to expand the field of freedom and enjoyment in liberty, and to vigorously resist any unlawful usurpation of such information.

In other words, the ethical journalism can only be the completely free journalism. And, a journalist with ethics is just a good professional, fully aware of the rules of the profession, and aware of the consequences when those rules are abused or violated (Prvulovic et.al., 2009).

Journalism ethics is important for the credibility, and it lies in personal fostering of humanity and truth.

Dennis McQuail, one of the most famous theorists of mass communications, defined journalism ethics using the following guidelines:

- truth and accuracy
- impartiality and fairness

- respect of personality and privacy

- independence from specific interests

- responsibility towards society and social goods

- respect of the law

- morality, decency and good taste

Observing the above-mentioned guidelines, we can say with certainty that many of them were breached by journalists. Conscious concealment of information, inventing of events, not using at least two independent sources to verify the information, inaccurate and distorted passing of information received from the source, distortion of truth are just some of their unethical procedures.

Such claims are proved by the research of Strategic Marketing, conducted for the needs of NUNS (Independent Association of Journalists of Serbia) on a sample of 1000 respondents. The respondents, largely recognize the importance of the journalist profession in the society, but they have described the state of the profession as very poor (Figure 1).

\begin{tabular}{rl|l|l|l|}
$\begin{array}{r}\text { Canard - the placement } \\
\text { of untruths, lies } \\
\text { Information }\end{array}$ \\
\cline { 2 - 5 }
\end{tabular}

Figure 1: When you hear the word Journalist, what first comes to mind-first noted (base total population)

According to the results of this extensive research conducted on a sample of 1,000 respondents living on the territory of Central Serbia, Vojvodina and Belgrade, the journalist profession in our country could not bear a description of being ethical and moral, because most of the citizens think that it is heavily politicized and insufficiently informative (Figure 2). 


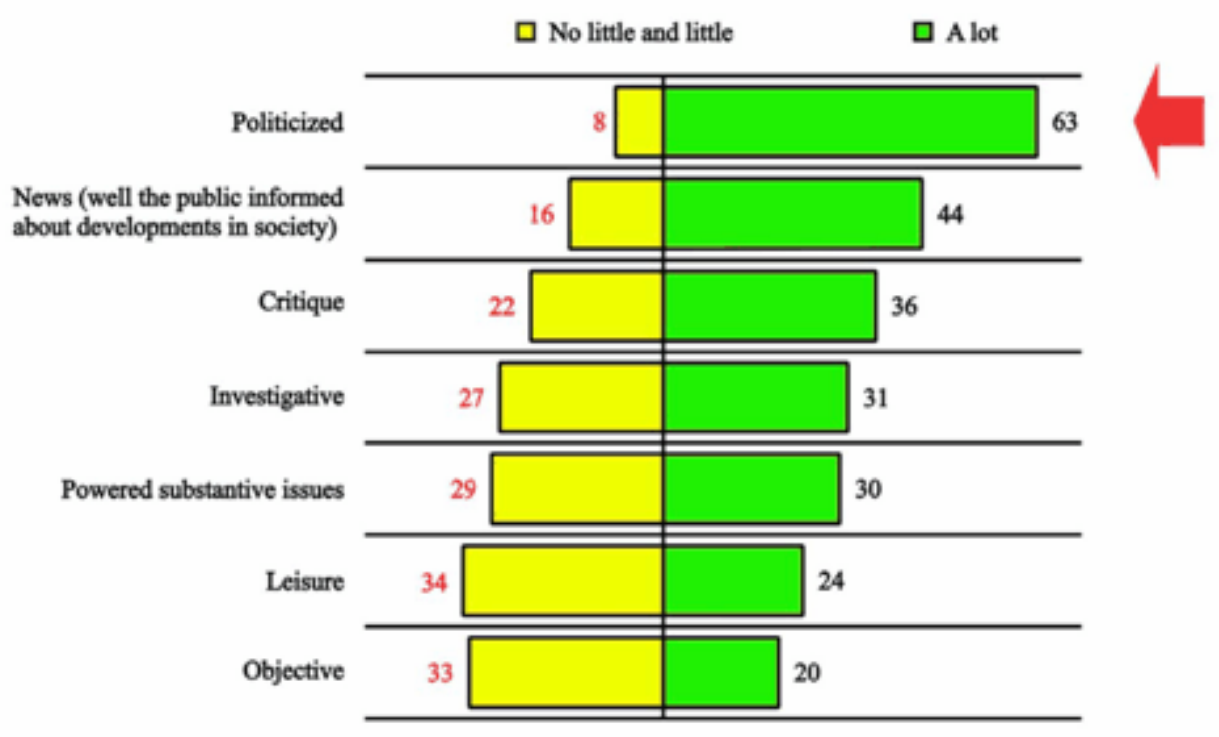

Figure 2: What iz generally journalism in our society (base: total population)

\section{RESULTS AND DISCUSSION}

For the purposes of this paper a survey was conducted, which included 300 respondents ranging from 20 to 50 years of age. All respondents received identical questionnaires with the help of which we were supposed to check what their statement about the basic ethical principles would be and the principles they consider important, define how much time they spend with media content, answer questions about journalism ethics, and give their opinion on the state of ethics in media today. Questions were ranked from 1 to 5 , where 1 - means I completely disagree, 2 - I disagree, 3 - I am indecisive, 4 - I agree, and 5 means I fully agree. The answers were provided by circling the corresponding number that is described as:

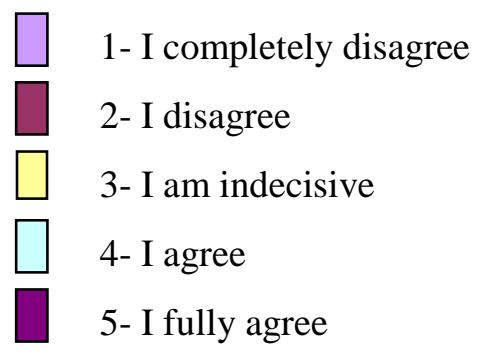

A certain group of questions aimed to determine how much time the respondents in Serbia spend with the media content and their relation towards that content, and especially towards advertisements. For this, 181 respondents (60\%) said they regularly read daily newspapers (grades 4 and 5), while 119 respondents (40\%) said they did not read or read irregularly daily newspapers (grades 2 and 3) - Figure 3.

Unlike the results regarding the newspapers, 207 respondents $(69 \%)$ said they regularly watch news broadcasts, 66 of them (22\%) said they do not watch regular news program on television, and 27 respondents or $9 \%$ were indecisive on this issue Figure 4.

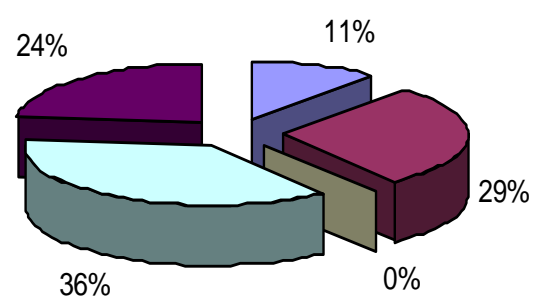

Figure 3:I regularly read daily newspapers

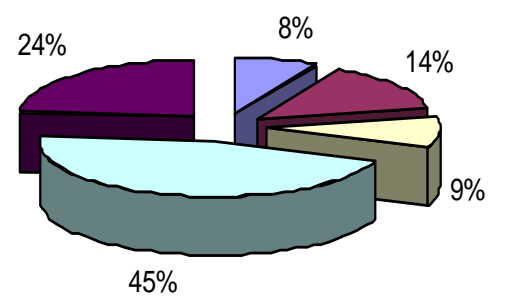

Figure 4:I regularly watch news program on TV

The second group of questions was related to their views regarding journalism ethics. According to results of the carried out survey, 239 respondents (79\%) has high respect for having ethics as a characteristic in journalism profession, 41 respondents (14\%) has no specific position on this issue and 20 respondents or $7 \%$ disagreed with this 
statement - Figure 5. With the statement: I believe that journalists are corrupt in our country 283 or even $95 \%$ respondents agreed, 10 or $3 \%$ of the respondents disagreed, while 7 or $2 \%$ respondents were indecisive - Figure 6 .

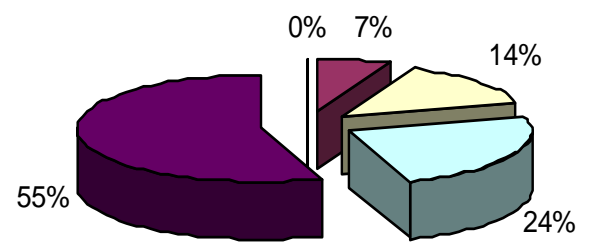

Figure 5:I highly respect journalism ethics

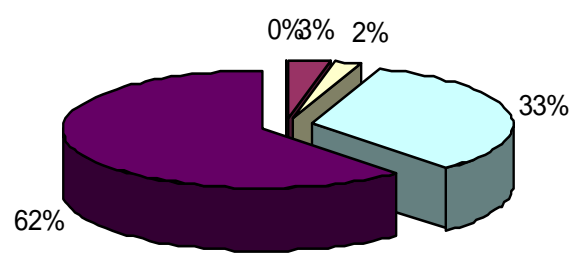

Figure 6:I believe that the journalists in our country are corrupt

With the statement that the journalism ethics can easily be controlled by ethical codes 176 or $58 \%$ respondents agreed, 29 or $10 \%$ indecisive respondents, while 95 or $32 \%$ respondents disagreed - Figure 7.

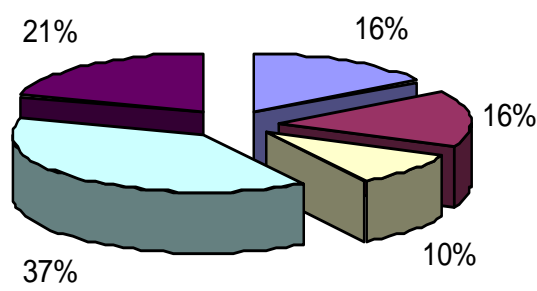

Figure 7 : I believe that journalism ethics can easily be controlled by ethical codes

Another important response obtained by the completion of the survey was related to how much, according to the assessment of the respondents, the ethics of journalists working in the media can be controlled by the rules adopted by various institutions and bodies or the ethics is though a matter of internal assessment of a person. 261 Respondents or $86 \%$ disagreed with the statement, while 34 respondents or $12 \%$ disagreed. This confirmed the thesis given in the paper that ethics of the journalists cannot be imposed, as well as the fact that the respondents in a greater number believe that the ethics of the profession depends on the ethics of a person, in this case the journalist Figure 8 .

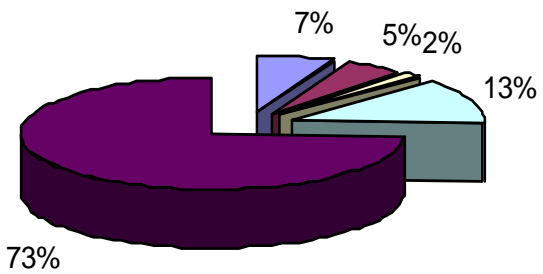

Figure 8 :Journalism ethics primarily depends on ethical standards of the journalists themselves

The next statement obtained from the survey was set in a way to find out in which degree it is believed that the journalist profession in Serbia is independent from politics and influence from the ruling political parties. In relation to this claim, a number of the respondents believe that journalism is often in the function of the ruling political elite 264 respondents or $87 \%$ agreed, while 34 respondents or $12 \%$ disagreed, and there were 2 or $1 \%$ of the undecided respondents. Such responses to the set statement talk about a very negative image that people have about journalists - Figure 9.

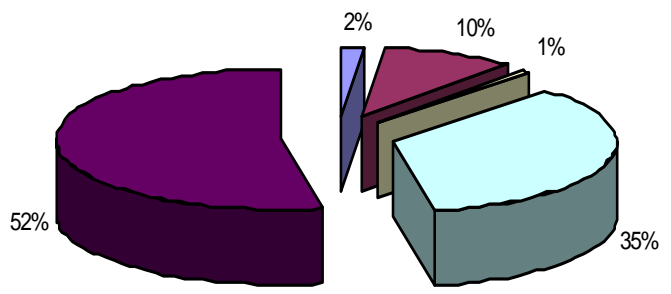

Figure 9: Journalists in our country are very often in the function of the ruling political elite

\section{CONCLUSION}

It can be concluded that the truth is essential to the democratic process. Democracy depends on informed citizens who approach the political and economic market with the knowledge that encourages analytical thinking. In a complex democratic society, the media are primary conductors of the flow of information. In the amount of providing untrue, inaccurate and irrelevant information, the media deny its audience the intellectual food necessary for rational decision-making. Of course, there is nothing ethically wrong with the desire of the media to meet the taste of the audience (McLuhan, 2001). The media must share moral responsibility for the decline of democratic values to the extent to which 
the public has given up on serious content in exchange for banality.

Morality as a virtue must not be a by-product of memorizing a certain number of rules or abstract principles. Ethical correctness requires commitment, reflection, and persistence. It requires a certain level of moral knowledge and ability of moral reasoning as well. Ethical standards of media professionals are not separated from the rest of the society. Those who work in the media need to resolve their ethical dilemmas through the same process of moral reasoning as well as everyone else. The media are an important transmission of our moral heritage. In this era of information, they are in the whirl of democratic events. This means that media representatives and journalists have a special responsibility towards the culture of which they are a part and they need to be aware that they are given a professional mandate to improve ethical climate within their institutions.

\section{REFERENCES}

Calabrese, A. (2007). Historical memory, media studies and journalism ethics. Global Media and Communication, 3(3), 363-370.
Carr, A. (1968). Is Business Bluffing Ethical? Harvard Business Review, 46(1), 143-153.

Day, L. A. (2004). Etika u medijima - primeri $i$ kontraverze. Beograd: Media centar.

Guilmot, J.-L. (2008). Media and ethics: Misunderstood requirement? Journal des Maladies Vasculaires, 33(2), 67-68. doi: 10.1016/j.jmv.2008.02.005

Himelboim, I., \& Limor, Y. (2008). Media perception of freedom of the press: A comparative international analysis of 242 codes of ethics. Journalism, 9(3), 235-265 doi: 10.1177/1464884907089007

Hitt, M. A., \& Collins, J. D. (2007). Business Ethics, Strategic Decision Making and Firm Performance. Business Horizons, 50(5), 353-357.

Marjanović, R. (2008). 'Etički kodeksi' i poslovna etika. Poslovna politika, 37(8-9), 73-76.

McLuhan, M. (2001). Understanding Media: The Extensions of Man (2nd ed.): Routledge Classics.

Prvulović, S. (2006). Poslovna etika i uprava. Bor: Tehnički fakultet Bor.

Prvulović, S., Štrbac, N., \& Vuković, M. (2009). Uticaj poslovne etike na društvenu odgovornost $\mathrm{i}$ marketing preduzeća. Poslovna politika, 38(3-4), 6469.

White, A. H. (1996). The Salience and Pertinence of Ethics: When Journalists do and Don't Think for themselves. Journalism \& Mass Communication Quarterly, 73(1), 17-28. doi: $10.1177 / 107769909607300103$ 